\title{
Anatomy of Deltoid Flap Based on Posterior Subcutaneous Deltoid Artery: A Cadaveric Investigation
}

\author{
Anatomía del Colgajo Deltoideo Basado en la Arteria \\ Subcutánea Deltoidea Posterior: Una Investigación en Cadáver
}

Edizer, M.*; Tayfur, V.**; Magden, A. O."; Atabey, A.***; Gocmen-Mas, N."; Aksu, F.* \& Karabekir, S.****

EDIZER, M.; TAYFUR, V.; MAGDEN, A. O.; ATABEY. A.; GOCMEN-MAS, N.; AKSU, F. \& KARABEKIR, S. Anatomy of deltoid flap based on posterior subcutaneous deltoid artery: a cadaveric investigation. Int. J. Morphol., 32(2):404-408, 2014.

SUMMARY: The purpose of the study is to evaluate neurovascular anatomy of the deltoid flap based on the posterior subcutaneous deltoid artery (PSDA). Bilateral axillary artery dissections of the thirty-four shoulders of 17 formalin-fixed cadavers were performed (15 male, 2 female; age range 40 to 82 years) under the 4x loupe magnification. During the dissection of each region, the PSDA was evaluated with respect to the origin, the branches, course and anatomical relations with neighbouring structures. The PSDA was present in all cases. The PSDA was single in $26(76.5 \%)$ cases, double in $2(5.9 \%)$ cases and had early bifurcation in $6(17.6 \%)$ cases. The mean length of the lateral cutaneous brachial nerve was $6.0 \mathrm{~mm}$ range from $49.0 \mathrm{~mm}$ to $83.9 \mathrm{~mm}$. The mean distance between the piercing point of the PSDA and the acromion was $74.2 \mathrm{~mm}$ range from $51.0 \mathrm{~mm}$ to $96.3 \mathrm{~mm}$. The pedicle bifurcated before reaching the superficial fascia in 6 cases $(17.6 \%)$. An anatomic study of the posterior subcutaneous deltoid artery achieves reliable quantitative anatomic data and would be very helpful for utilizing deltoid flap. The quantitative and detailed anatomic information provided from the study may be of guidance to surgeons for safe operating period.

KEY WORDS: Deltoid flap; Reconstruction; Posterior circumflex humeral artery; Posterior subcutaneous deltoid artery.

\section{INTRODUCTION}

Posterior subcutaneous deltoid artery (PSDA) is a branch of the posterior circumflex humeral artery (PCHA) originating from the third section of the axillar artery which is sited between inferior margin of the minor pectoral muscle and inferior margin of the teres major muscle (Williams et al., 1995; Moore, 1992; Hue et al., 1998). Classically, the origin of the PSDA locates on crossing point of the line between the acromion and the medial epicondyle with the posterior margin of the deltoid muscle (Cormack \& Lamberty, 1994). The artery is larger than the other perforating arteries and comprises the basis of the deltoid flap (Munnoch et al., 1996).

The first anatomical and clinical identification and definition of the deltoid flap were declared by Franklin (Franklin, 1984; Wang et al., 2003). Munnoch et al., claimed that the dorsal part of the deltoid muscle could use in a local muscle flap. The anterior part of it could be used as a musculocutaneous flap.

Deltoid flap is an important option on therapy for radionecrotic ulcers of the soft tissue after radiotherapy (Munnoch et al.; Löw et al., 2014). Hue et al., declared that, the deltoid flap was only supplied by its inferior side and had insufficient anastomotic network. The features might lead to flap necrosis.

The neuromuscular component of the posterior deltoid muscle which is supplied by the PCHA is completely separated from the other parts, therefore the muscle transfer becomes easier for the tetraplegic patients (Hong et al., 2005). The deltoid flap is obtained through removing the PSDA based free pedicle during the flap surgery (Franklin; Augereau \& Apoil, 1988; Cormack \& Lamberty, 1984). The purpose of the study is to evaluate neurovascular anatomy of the deltoid flap based on the PSDA.

\footnotetext{
* School of Medicine, Anatomy Department, Dokuz Eylul University, Izmir, Turkey.

** Plastic Surgeon, Ankara, Turkey.

*** Plastic Surgeon, Izmir, Turkey.

**** School of Medicine, Neurosurgery Department, Dokuz Eylul University, Izmir, Turkey.
} 


\section{MATERIAL AND METHOD}

Cadaveric design. In the present study, bilateral axillary artery dissections of the thirty-four shoulders of 17 formalinfixed cadavers were performed ( 15 male, 2 female; age range 40 to 82 years) under the $4 \mathrm{X}$ loupe magnification. The measurements were provided with the aid of a fine microcaliper and expressed in millimeters. The PSDA and the origin of PCHA were exposed in all cadavers.

The following parameters regarding the PSDA were indicated (Figs. 1-3) and evaluated as following parameters; (1) the origin; (2) the mean diameter of the artery at its origin; (3) the mean length of the artery; (4) the mean distance between origin of the artery and the acromion; (5) the mean distance between origin of the artery and the long head of triceps brachii muscle; (6) the mean distance between the origin of the artery and the point of the acromion-medial epicondyle line with crossing the posterior border of the deltoid muscle (6.1), the mean distance between origin of the artery and crossing point of line between the acromion medial epicondyle line with the posterior margin of the deltoid muscle; (7) the mean distance between origin of the artery and the deltoid tuberosity; (8) presence of the PSDA as single or double; (9) placement of the PSDA according to the teres major muscle; (10) presence of the comitantes veins; (11) presence of accompanied with the lateral cutaneous brachial nerve; (12) the length of the lateral cutaneous brachial nerve; (13) the mean distance between the piercing point of the PSDA and the acromion; (14) pedicle features.

\section{RESULTS}

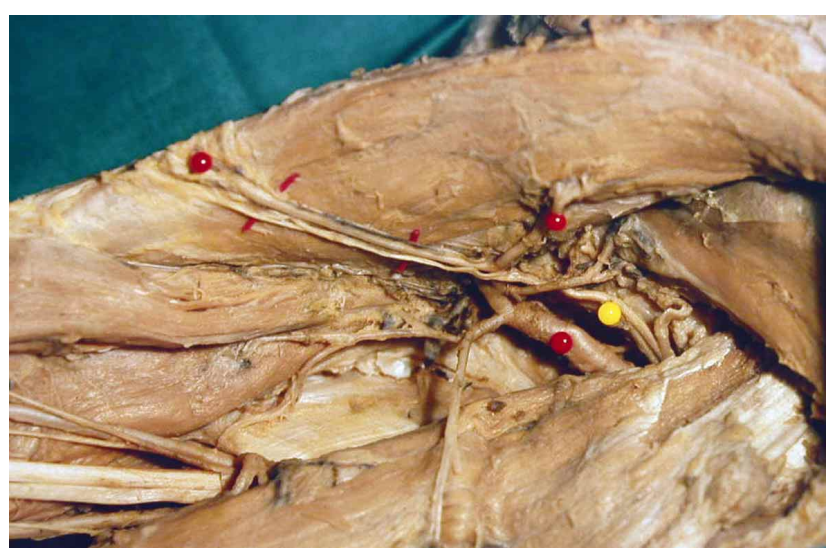

Fig. 1. One pedicule at the origin. 1. PCHA= Posterior circumflex humeral artery. 2. PSDA= Posterior subcutaneous deltoid artery. 3. $\mathrm{CP}=$ Comitantes veins. 4 . $\mathrm{LBCN}=$ Lateral brachial cutaneous nerve. $5 . \mathrm{DM}=$ Deltoid muscle. 6 . TMaj= Teres major muscle. 7 . $\mathrm{LM}=$ Long head of tricep brachii muscle. 8. TMin= Teres minor muscle.
During the dissection of each region, the PSDA was evaluated with respect to the origin, the branches, course and anatomical relations with neighbouring structures. The pedicle and the PSDA were examined by the microdissection method on the cadavers, and the findings were carefully noted as the mean of the pedicle length was 53.0 $\mathrm{mm}$. The artery arose separately from the PCHA in all cases. The artery also originated from the axillar artery in all cases.

At the level of origin point on the axillary artery, the size of the PSDA had the mean of $0.96 \mathrm{~mm}$ ranged from $0.81 \mathrm{~mm}$ to $1.33 \mathrm{~mm}$. The mean length was $51.10 \mathrm{~mm}$ (ranged from $34.0 \mathrm{~mm}$ to $64.20 \mathrm{~mm}$ after piercing the deltoid muscle, and the mean total length was $75.40 \mathrm{~mm}$ during the course range from $62.12 \mathrm{~mm}$ to $87.20 \mathrm{~mm}$. The distance between the origin of the artery and the acromion was found to be $53.0 \mathrm{~mm}$ range from $41.0 \mathrm{~mm}$ to $64.3 \mathrm{~mm}$. The distance between the origin of the artery and long head of the triceps brachii muscle was found to be $8.74 \mathrm{~mm}$ ranged from 1.02 $\mathrm{mm}$ to $19.88 \mathrm{~mm}$. The artery locates on a crossing point between the imaginary line (from the acromion to the medial epicondyle) and the posterior margin of the deltoid muscle (Cormack \& Lamberty, 1994). However, the location point of the artery diverged from the classical location as the mean of $16.14 \mathrm{~mm}$ range from $6.04 \mathrm{~mm}$ to $34.38 \mathrm{~mm}$. The distance between origin of the artery and the deltoid tuberosity was mean $95.10 \mathrm{~mm}$ range from $76.20 \mathrm{~mm}$ to $119.62 \mathrm{~mm}$. The

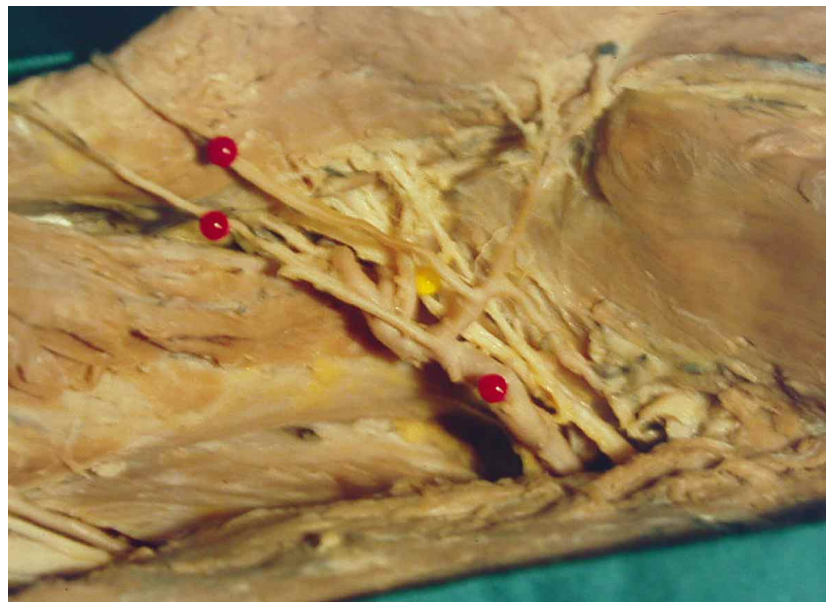

Fig. 2. One pedicule at the origin, after that two pedicules. 1. $\mathrm{PCHA}=$ Posterior circumflex humeral artery. 2. PSDA= Posterior subcutaneous deltoid artery. 3. $\mathrm{CP}=$ Comitantes veins. $4 . \mathrm{MB}=$ PCHA from the deltoid muscle to the outgoing branch. 5. $\mathrm{LBCN}=$ Lateral brachial cutaneous nerve. 6. DM= Deltoid muscle. 
PSDA was present in all cases. The PSDA was single in 30 $(88.24 \%)$ cases, double in $4(11.76 \%)$ cases and had early bifurcation in $6(17.65 \%)$ cases (Figs. 1-3). The PSDA lay behind the teres major muscle in al cases. The comitantes veins were observed in all cases. The lateral cutaneous brachial nevre accompanied with the PSDA in all of the cases. The mean length of the lateral cutaneous brachial nerve was $64.10 \mathrm{~mm}$ range from $49.0 \mathrm{~mm}$ to $84.0 \mathrm{~mm}$. The mean distance between the piercing point on the superficial fascia of the PSDA and the acromion was $74.22 \mathrm{~mm}$ range from $51.08 \mathrm{~mm}$ to $96.32 \mathrm{~mm}$ ). The pedicle bifurcated before reached the superficial fascia in 6 cases $(17.65 \%)$ (Fig. 2).

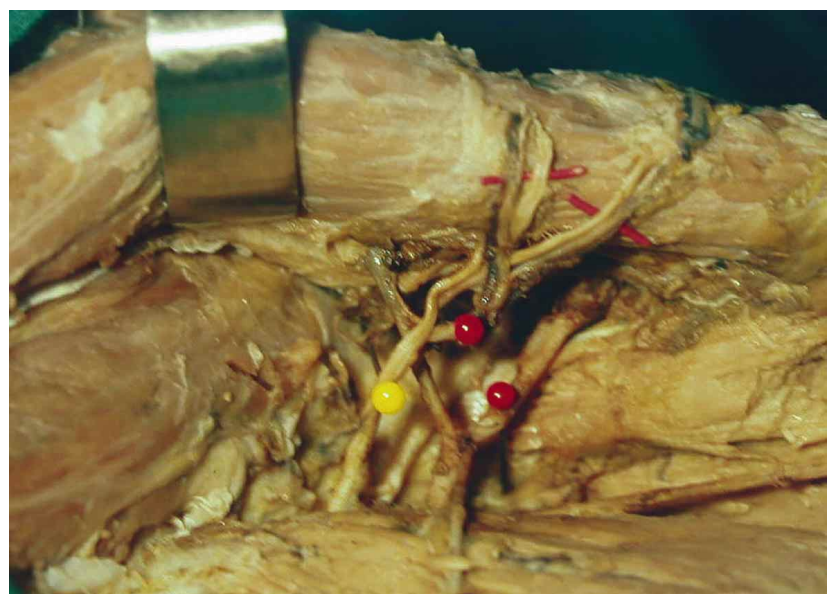

Fig. 3. Double pedicul at the origin. 1. PCHA= Posterior circumflex humeral artery. 2. PSDA= Posterior subcutaneous deltoid artery. 3. $\mathrm{AN}=$ Axillar nerve. $4 . \mathrm{DM}=$ Deltoid muscle. 5 . $\mathrm{TMin}=$ Teres minor muscle.

\section{DISCUSSION}

The deltoid muscle has been evaluated by many authors in various clinical events such as rotator cuff tears (Schneeberger et al., 2012; Vandenbussche et al., 2004), neck and orofacial reconstruction (Nthumba, 2012; Hong et al.). The anatomical architecture of the deltoid flap was classified according to their vascular features (Wang et al.). The first anatomical and clinical identification and also implementation of a deltoid flap was made by Franklin (Franklin; Wang et al.).

The advantages of this flap are relatively thin and hairless, and also have reliable sensory and neurovascular features. Furthemore, the flap based on the PCHA also allows easy and safe transference. In order to prevent humeral cranial migration and cuff-tear arthropathy (Wiley), several surgeons prefered to use the deltoid muscle flap for reconstruction of massive rotator cuff tears as described by Apoil \& Augereau (Apoil \& Augereau, 1985; Augereau \&
Apoil). The disadvantages are visible scar in the donor area, possible axillary nerve injuries, and early bifurcation or existing doube pedicles.

Deltoid flap is obtained through removing pedicle of the ADSP during the free flap surgery (Franklin; Apoil \& Augereau; Cormack \& Lamberty, 1994). Deltoid flap is a fasciocutaneous flap which should be thin, hairless, of appropriate size and full sensory innervation (Wang et al.). The flap which is generally $7 \times 15 \mathrm{~cm}$ in size may also be used in the reconstruction of the upper and lower lips, face and penis as the sensory flap (Russel et al., 1985; Volpe et al., 1997; Harashina et al., 1990; Cormack \& Lamberty, 1994; Serafin, 1996; Mathes \& Nahai, 1997; Munnoch et $a l$. .). The flap is relatively narrower than the other flaps, which is removed from the same area. This flap has been used so far in reconstructive surgery including oral and maxillofacial surgery (Wang et al.).

The PSDA is a branch of the PCHA. The artey arises from the third section of the axillar artery which is placed between the bottom edge of the minor pectoral and the bottom edge of the teres major muscles. The artery is larger than the other perforating arteries on brachial region as it also forms the basis of deltoid flaps (Munnoch et al.). Recent investigations on vascular supply of the deltoid flap showed that the PCHA harvested thedorsal and the middle sections of the deltoid muscle (Hue et al.) was similiar with our data. Some research on anatomical features of the axillary nerve presented that the posterior part of deltoid muscle was innervated in 90 percent of the cases by the posterior branch of the axillary nerve. In 10 percent, innervation was entirely by the anterior branch (Hong et al.). Wang et al., declerated that range of the size of the posterior circumflex humeral artery was range between 1.32 and $0.25 \mathrm{~mm}$. In literature, the size of the PSDA was noted as $0.75-1.5 \mathrm{~mm}$ (Mathes \& Nahai), 2-4 $\mathrm{mm}$ (Serafin) and $0.88-0.19 \mathrm{~mm}$ (Wang et al.). We found that size of the PSDA was mean $0.96 \mathrm{~mm}$ ranged from $0.81 \mathrm{~mm}$ to 1.33 $\mathrm{mm}$. Mean distance between the origin of the artery and the point of the acromion-medial epicondyl line with crossing the posterior border of the deltoid muscle was mean $16.1 \mathrm{~mm}$ range from $6.0 \mathrm{~mm}$ to $34.3 \mathrm{~mm}$.

According to the classical textbook, the origin of PSDA locates on crossing point of the line between the acromion and medial epicondyle with the posterior margin of the deltoid muscle (Cormack \& Lamberty, 1994), however, we measured distance between the origin of the artery from that crossing point as mean $16.1 \mathrm{~mm}$ range from $6.0 \mathrm{~mm}$ to $34.3 \mathrm{~mm}$. According to our observation the lateral cutaneous brachial nerve was accompanied with the PSDA in 34 cases. 
The results of several studies show that the mean pedicle length of the deltoid flap was 3-4 $\mathrm{cm}$ (Mathes \& Nahai) and 6-8 $\mathrm{cm}$ (Serafin). We found that the mean pedicle length was be $53.0 \mathrm{~mm}$ range from $41.0 \mathrm{~mm}$ to $64.3 \mathrm{~mm}$.

Some discordant points on course of vascular and neural structures of the deltoid muscle were declared in literature. Franklin claimed that the neurovascular structures passed into the deltoid flap, but it was found that the pedicle passed entirely through the "quadrangular space" (Cormack \& Lamberty; Franklin).

We found that the PSDA was double in $2(5.9 \%)$ of the cases. The artery also runs together with the comitantes veins in all cases. Surgeons should pay attention to this type of variation and vein course. The study of PSDA features may be important for flap surgery.

\section{CONCLUSION}

An anatomic study of the posterior subcutaneous deltoid artery achieves reliable quantitative anatomic data would be very helpful for utilizing deltoid flap. The detailed and quantitative anatomic information provided from the study may be of guidance to surgeons for safe operating period.

EDIZER, M.; TAYFUR, V.; MAGDEN, A. O.; ATABEY. A.; GOCMEN-MAS, N.; AKSU, F. \& KARABEKIR, S. Anatomía del colgajo deltoideo basado en la arteria subcutánea deltoidea posterior: Una investigación en cadáver. Int. J. Morphol., 32(2):404-408, 2014.

RESUMEN: El objetivo del presente estudio fue evaluar la anatomía neurovascular del colgajo deltoideo basado en la arteria subcutánea deltoidea posterior (ASDP). Se realizaron disecciones axilares bilaterales de 34 hombros de 17 cadáveres (15 hombres y 2 mujeres con un rango etareo entre 40-82 años) fijados en formalina con ampliación mediante una lupa 4X. Durante la disección de cada región, la ASDP fue evaluada en relación con su origen, ramas, curso y relaciones anatómicas con estructuras vecinas. La ASDP estuvo presente en todos los casos. Observamos una ASDP en 26 casos (76,5\%), dos en 2 casos $(5,9 \%)$ y la bifurcación temprana en 6 casos $(17,6 \%)$. La longitud media del nervio cutáneo lateral braquial fue de 6,0 mm (intervalo de 49,0-83,9 mm). La distancia media entre el punto de entrada y el acromion de la ASDP fue 74,2 mm (rango de 51,0-96,3 mm). La bifurcación del pedículo se presentó antes de llegar a la fascia superficial en 6 de los casos (17,6 \%). El estudio anatómico de la parte posterior de la arteria deltoidea subcutánea entrega datos anatómicos, cuantitativos, fiables para la utilización del colgajo deltoideo. La información detallada y cuantitativa proporcionada en este estudio puede servir de orientación a los cirujanos para un abordaje y período quirurgico seguro.

PALABRAS CLAVE: Colgajo deltoideo; Reconstrucción; Arteria humeral circunfleja posterior; Arteria deltoidea subcutánea posterior.

\section{REFERENCES}

Apoil, A. \& Augereau, B. Deltoid flap repair of large losses of substance of the shoulder rotator cuff. Chirurgie, 111(3):28790, 1985.

Augereau, B. \& Apoil, A. Repair using a deltoid flap of an extensive loss of substance of the rotary cuff of the shoulder. Rev. Chir. Orthop. Reparatrice Appar. Mot., 74(4):298-301, 1988.

Cormack, G. C. \& Lamberty, B. G. The arterial anatomy of skin flaps. $2^{\text {nd }}$ ed. Edinburgh, Churchill-Livingstone, 1994.

Cormack, G. C. \& Lamberty, B. G. Fasciocutaneous vessels in the upper arm: application to the design of new fasciocutaneous flaps. Plast. Reconstr. Surg., 74(2):244-50, 1984.

Franklin, J. D. The deltoid flap: anatomy and clinical applications. In: Bunke, H. J. \& Furnas, D. W. (Eds.). Symposium on clinical frontiers in reconstructive microsurgery. St. Louis, CV Mosby, 1984. pp.63-70. Vol.24.
Harashina, T.; Inoue, T.; Tanaka, I.; Imai, K. \& Hatoko, M. Reconstruction of penis with free deltoid flap. Br. J. Plast. Surg., 43(2):217-22, 1990.

Hong, T. C.; Kumar, V. P. \& Nather, A. The posterior neuromuscular compartment of the deltoid. Plast. Reconstr. Surg., 115(6):16604, 2005 .

Hue, E.; Gagey, O.; Mestdagh, H.; Fontaine, C.; Drizenko, A. \& Maynou, C. The blood supply of the deltoid muscle. Application to the deltoid flap technique. Surg. Radiol. Anat., 20(3):161-5, 1998.

Löw, S.; Herold, D. \& Eingartner, C. Pediculated deltoid muscle flap: An alternative for coverage of chronic radionecrotic lesions in the shoulder region. Unfallchirurg, DOI 10.1007/s00113-0132435-9, 2014.

Mathes, S. J. \& Nahai, F. Reconstructive surgery: principles, anatomy, \& technique. New York, Churchill Livingstone, 1997. 
EDIZER, M.; TAYFUR, V.; MAGDEN, A. O.; ATABEY. A.; GOCMEN-MAS, N.; AKSU, F. \& KARABEKIR, S. Anatomy of deltoid flap based on posterior subcutaneous deltoid artery: a cadaveric investigation. Int. J. Morphol., 32(2):404-408, 2014.

Moore, K. L. Clinically Oriented Anatomy. $3^{\text {rd }}$ ed. Baltimore, Williams \& Wilkins, 1992.

Munnoch, D. A.; Herbert, K. J.; Morris, A. M. \& Stevenson, J. H. The deltoid muscle flap: anatomical studies and case reports. Br. J. Plast. Surg., 49(5):310-4, 1996.

Nthumba, P. M. The supraclavicular artery flap: a versatile flap for neck and orofacial reconstruction. J. Oral Maxillofac. Surg., 70(8):1997-2004, 2012.

Rusell, R. C.; Guy, R. J.; Zook, E. G. \& Merrell, J. C. Extremity reconstruction using the free deltoid flap. Plast. Reconstr. Surg., 76(4):586-95, 1985.

Serafin, D. G. Atlas of microsurgical composite tissue transplantation. Philadelphia, Saunders, 1996.

Schneeberger, A. G.; Schuler, L.; Rikli, D. \& Thür, C. Rotator cuff tears treated with a modified deltoid flap repair technique. $J$. Shoulder Elbow Surg., 21(3):310-8, 2012.

Vandenbussche, E.; Bensaïda, M.; Mutschler, C.; Dart, T. \& Augereau, B. Massive tears of the rotator cuff treated with a deltoid flap. Int. Orthop., 28(4):226-30, 2004.

Volpe, C. M.; Peterson, S.; Doerr, R. J. \& Karakousis, C. P. Forequarter amputation with fasciocutaneous deltoid flap reconstruction for malignant tumors of the upper extremity. Ann. Surg. Oncol., 4(4):298-302, 1997.

Wang, Z.; Sano, K.; Inokuchi, T.; Li, J.; Lan, X.; Sekine, J. \& Ikeda, $\mathrm{H}$. The free deltoid flap: microscopic anatomy studies and clinical application to oral cavity reconstruction. Plast. Reconstr. Surg., 112(2):404-11, 2003.

Wiley, A. M. Superior humeral dislocation. A complication following decompression and debridement for rotator cuff tears. Clin. Orthop. Relat. Res., (263):135-41, 1991.

Williams, L. P.; Bannister, L. H.; Berry, M. M.; Collins, P.; Dyson, M.; Dussek, J. E.; \& Ferguson, M. W. J. Gray's Anatomy. $38^{\text {th }}$ ed. London, Churchill Livingstone, 1995.

\author{
Correspondence to: \\ Ass. Prof. Dr. Funda Aksu \\ Dokuz Eylül University Medical Faculty \\ Department of Anatomy \\ 35340 Inciralti \\ Izmir \\ TURKEY
}

Tel: $+90(232) 4124361$

Fax. +90[232] 4129798

Email: funda.aksu@deu.edu.tr

Received: 12-10-2013

Accepted: 08-01-2014 